\title{
Effect of breed (wool and hair) and sex on the carcass quality of suckling lambs under intensive management
}

\author{
Ángeles Camacho ${ }^{1}$, Juan Capote ${ }^{2}$, Javier Mata ${ }^{1}$, Anastasio Argüello ${ }^{3}$, Juan J. Viera ${ }^{4}$, \\ Luis A. Bermejo ${ }^{1,4}$
}

\footnotetext{
${ }^{1}$ Group of Animal Production and Rural Development. Department of Engineering, Production and Agricultural Economy. La Laguna University, La Laguna, Spain.

2 Instituto Canario de Investigación Agraria, La Laguna, Tenerife, Spain.

${ }^{3}$ Animal Production Unit. Las Palmas de Gran Canaria University, Arucas, Spain.

${ }^{4}$ Agricultural Economy, Sociology and Policy Unit. Department of Engineering, Production and Agricultural Economy. La Laguna University, La Laguna, Spain.
}

ABSTRACT - Carcasses of twenty lambs (10 males and 10 females) from the Canaria Hair breed (CHB) and another twenty (10 males and 10 females) from the Canaria breed (CB) of $9.91 \pm 0.73 \mathrm{~kg}$ and $9.87 \pm 0.80 \mathrm{~kg}$ live weight, respectively, were studied. In the principal component (PC) analysis, the projection of carcass measurement data in the first PC allowed for clearly distinguishing between $\mathrm{CB}$ and $\mathrm{CHB}$. In the analysis of variance, breed effect was observed in the morphology of the carcass: CB lambs showed the longest carcasses and CHB lambs showed the widest carcasses. Due to their wider rump and shorter legs, CHB lambs presented a more compact leg index. The carcasses from Canaria lambs had the highest fat score, the heaviest shoulder and the highest total fat percentage. The carcasses from CHB lambs showed a higher lean percentage. The carcass yield, conformation, degree of fatness and tissue composition were similar in both sexes. However, significant differences in the commercial cut yield were observed: males showed heavier shoulders than females. The effect of sex on carcass quality is unimportant. The breeds are different in important characteristics for the market, such as fatness. This fact is of significant interest because it diversifies the offer and means that different markets can be satisfied.

Key Words: carcass quality, intensively managed, local genetic resource, sheep

\section{Introduction}

In the Canary Islands (Spain), three local sheep breeds are considered native, and qualify for special protection (R.D. 2129/2008): the Canaria (wool), the Palmera (wool) and the Canaria Hair (CHB). Although the population of these sheep increased by $51.57 \%$ between 2000 and 2010 , the total number of animals was still only 80,304 . In particular, the hair sheep population has increased in recent years. There are several reasons that explain the increase in CHB, the only hair breed in Europe (Bermejo et al., 2010): management requirements of hair breeds are simpler than those of wool breeds because they do not require shearing; their resistance to certain parasites, such as Haemonchus contortus (González et al., 2008); and hair breeds also show good productive performance in hot climates with high humidity (Camacho et al., 2010). These characteristics and the availability of agricultural by-products like feed (Camacho et al., 2011) make it an interesting breed for many areas such as southern Spain, where greenhouse farming generates large amounts of byproducts. Contrary to hair sheep, wool breeds (Canaria and
Palmera) have reduced their numbers in the recent years, especially the Palmera breed (Hernández-Castellano, 2010). Although these breeds are used mainly for milk production, lamb meat is an interesting complement to the farm economy.

A deficit in sheep products is often observed in the Canary Islands. Sheep meat production was $1,591 \mathrm{t}$ live weight in 2010, an amount lower than the demand (GOBCAN, 2010). Traditionally, the type of lamb produced is suckling lamb because of the large number of dairy sheep (wool) (Cañeque et al., 2004). Local breeds could be the basis of a meat production of certified quality (Protected Designation of Origin, Protected Geographical Indication or similar); however, the quality of sheep products must first be characterised and evaluated. For some authors, breed (Civit et al., 2009) and sex (Rodríguez et al., 2008) affect the carcass quality of suckling lambs Therefore, the objective of the present study is to evaluate the effect of breed and sex on the growth and carcass characteristics of Canaria (dairy) and Canaria Hair (meat) suckling lambs slaughtered at the same live weight. 


\section{Material and Methods}

The present experiment complied with the norms of the Committee of Animal Research Ethics and Welfare of the University of La Laguna (R.D., 1202/2005; L., 14/2007). Twenty Canaria Hair (CHB) lamb carcasses (10 males and 10 females) and twenty Canaria (CB) lamb carcasses (10 males and 10 females) were studied. The animals were reared in the same conditions on a farm located in Tenerife (Canary Island, Spain) (28.07 N and $16.35 \mathrm{~W}$ ), where the average annual temperature is $20.2{ }^{\circ} \mathrm{C}$ and the relative humidity is $72 \%$. Three rams were used in each breed group and the breeding period began simultaneously in all groups. The average prolificacy was similar in both breeds.

The lambs were weighed at birth and were identified with a numbered collar. During the study, they were kept with their dams. The lambs were individually weighed each week until reaching their slaughter weight $(9.91 \pm 0.73 \mathrm{~kg}$ live weight and 47.9 days for $\mathrm{CHB}$ and $9.87 \pm 0.80 \mathrm{~kg}$ live weight and 51.1 days for $\mathrm{CB}$ ). The lambs were reared following a traditional production system. During the first week of their life, all received vitamins $\mathrm{A}, \mathrm{D}_{3}$ and $\mathrm{E}$ and were vaccinated against enterotoxemia. The lambs received maternal milk until they reached 15 days of age. After day 15 , milk-feeding was continued and free access to forage, concentrate $(1,530 \mathrm{kcal}$ of net energy and $18 \%$ crude protein) and water was initiated. Dams were fed ray-grass hay ad libitum, and a concentrate (1,638 kcal of net energy and $19 \%$ crude protein). When the lambs reached slaughter weight, they were transported to the slaughterhouse, according to EU regulations (Council Regulation (EEC) $\left.N^{0} 1 / 2005,2004\right)$. All of the animals were weighed twice, first at the farm, and then at the slaughterhouse, to identify losses due to transport. In the slaughterhouse, the animals were fasted (10-12 hours), and only water was provided (R.D. 54/1995). After measuring slaughter live weight (SLW), the lambs were electrically stunned and slaughtered according to standard commercial procedures.

The head, feet, skin, liver, heart, lung-trachea, spleen, thymus, testicle-penis, ovary-uterus and full and empty gastrointestinal tract of each lamb were weighed. The carcass included the kidneys, pelvic-renal fat and meaty portion of the diaphragm; however, the head (cut at occipitalatlantoidal articulation) and the limbs (cut at the carpometacarpal and tarso-metatarsal joints) were not included. The carcasses were weighed (hot carcass weight, HCW) and hung by the Achilles tendon after processing. Subsequently, the carcasses were cooled to $4{ }^{\circ} \mathrm{C}$ for 24 hours. After chilling, the carcasses were weighed again (cold carcass weight,
$\mathrm{CCW})$, and the carcass yield $(\mathrm{CCW} / \mathrm{SLW} \times 100)$ and shrink losses (calculated as the difference between the HCW and $\mathrm{CCW}$ and expressed as a percentage of the $\mathrm{HCW}$ ) were determined.

After cooling, various carcass measurements were determined to assess the carcass morphology, including the carcass length (K) (Boccard et al., 1964), rump width (G) (Palsson, 1939), maximum width at rib level (Wr) (Barton et al., 1949) and rump perimeter (B) (Robinson et al., 1956). Half carcasses were obtained according to the procedure described by Colomer-Rocher et al. (1988), and the half-carcass internal length (L) and leg length (F) were determined according to the methods of Palsson (1939) and McMeekan (1939), respectively. Carcass compactness index (CCW/L) (Palsson, 1939) and leg compactness index (G/F) (Thwaites et al., 1964) were calculated.

The subjective classification of conformation was evaluated using the description provided and photographic standards by Colomer-Rocher et al. (1988). In total, 15 categories were considered $(1=\mathrm{P}-; 2=\mathrm{P}$ (poor); $3=\mathrm{P}+$; $4=\mathrm{O}-; 5=\mathrm{O}$ (normal); $6=\mathrm{O}+; 7=\mathrm{R}-; 8=\mathrm{R}$ (good); $9=$ $\mathrm{R}+; 10=\mathrm{U}-; 11=\mathrm{U}$ (very good); $12=\mathrm{U}+; 13=\mathrm{E}-; 14=\mathrm{E}$ (excellent); and $15=\mathrm{E}+$ ). The carcass fatness was classified according to the EU scale (EEC Regulation 1278/94) for light lamb carcasses, which has 12 categories $(1=1-; 2=$ 1 (very scarce); $3=1+; 4=2-; 5=2$ (scarce); $6=2+; 7=$ $3-; 8=3$ (medium); $9=3+; 10=4-; 11=4$ (important), $12=4+)$. The carcasses were ribbed between the twelfth and thirteenth thoracic vertebrae to measure (with a manual calliper) fat thickness (fat depth). Subsequently, the carcasses were weighed and split down the dorsal midline. Half-left carcasses were also weighed and disjointed (Colomer-Rocher et al., 1988) into seven anatomical parts, including the leg, loin, anterior ribs, shoulder, breast, neck and tail. Each joint was weighed, and the value was expressed as a percentage of the cold carcass weight. The joints were vacuum packed, frozen and maintained at $-20{ }^{\circ} \mathrm{C}$ until dissection. The joints were grouped into the first (leg + loin + anterior ribs), second (shoulder) and third (breast + neck + tail) categories, according to Colomer-Rocher et al. (1988). Prior to dissection, the joints were defrosted in trays and placed inside a refrigerator. The dissection method of Colomer-Rocher et al. (1988) was followed to determine the tissue components (lean, subcutaneous fat, intermuscular fat, bone and remainders), and the percentage of bone, fat and lean were calculated. Moreover, lean/bone (L/B), lean/fat (L/F) and subcutaneous fat/intermuscular fat (SF/IF) ratios were also determined.

The data were analysed using SPSS (SPSS System, Inc., Chicago, USA, version 15.0). Principal components 
analysis was performed for carcass measurements $(\mathrm{K}, \mathrm{L}, \mathrm{F}$, $\mathrm{G}, \mathrm{B}$ and $\mathrm{Wr}$ variables) and tissue composition (L, TF, SF, IF and $\mathrm{B}$ variables). This analysis resulted in a graphical representation of the location of the observations in space made up of the functions obtained (component 1 and 2). The means were analysed by conducting an analysis of variance (ANOVA). The fixed effects of the model included the breed, sex and interaction effects of breed and sex. Differences among means were evaluated by conducting Scheffé's test.

\section{Results}

A principal component (PC) analysis performed on carcass measurements found that the first, two components explain $65.8 \%$ of total variation (Table 1 ). Maximum width at rib level (Wr), rump width (G) and leg length $(F)$ were the measurements with highest values in the components matrix $(0.862,0.796$ and -0.733 , respectively). The two breeds are separated by $90^{\circ}$ in the

Table 1 - Results from the principal component analysis for the six principal components of the carcass measurements

\begin{tabular}{lccc}
\hline Component & Eigenvalues & $\begin{array}{c}\text { Portion of variance } \\
(\%)\end{array}$ & $\begin{array}{c}\text { Cumulative variance } \\
(\%)\end{array}$ \\
\hline 1 & 2.15 & 35.82 & 35.82 \\
2 & 1.79 & 29.97 & 65.80 \\
3 & 1.02 & 17.15 & 82.96 \\
4 & 0.52 & 8.67 & 91.63 \\
5 & 0.29 & 4.90 & 96.54 \\
6 & 0.20 & 3.45 & 100.00 \\
\hline
\end{tabular}

first component (Figure 1). The sexes are located in the four quadrants (Figure 2).

The breed affected different carcass measurements and the fatness of the carcass (Table 2). Canaria lambs were characterised by longer carcass $(\mathrm{K})(\mathrm{P}<0.001)(41.25 \pm 1.44$ vs. $39.25 \pm 1.93)$ and $\operatorname{leg}(\mathrm{F})(\mathrm{P}<0.001)(26.03 \pm 2.19$ vs. $23.86 \pm 1.14)$, and thinner rump $(\mathrm{G})(\mathrm{P}<0.001)(10.50 \pm 0.76$ vs. $11.67 \pm 1.01)$ and thorax $(\mathrm{Wr})(\mathrm{P}<0.001)(10.63 \pm 1.04$ vs. $12.32 \pm 0.96)$. Canaria-hair-breed lambs presented carcasses with a more compact leg (G/F) $(0.49 \pm 0.04$ vs. $0.40 \pm 0.04)$ due to the wider rump and smaller leg length $(\mathrm{P}<0.001)$. Canaria lambs showed higher fatness scores $(5.95 \pm 1.92$ vs. 3.68 \pm 1.76$)(\mathrm{P}<0.001)$. Sex did not affect any of the aforementioned variables (Table 2).

A Principal component analysis carried out on tissue composition of the carcass showed that the first two components explain $80 \%$ of total variation (Table 3 ). Total fat (TF) and subcutaneous fat (SF) were the variables with the highest values in the components matrix (0.929 and 0.864 , respectively). There are no differences in the location of the breeds and sexes (Figure 3 and 4). The carcasses of CB lambs are located only in the positive zone of the first component (Figure 3).

Breed did not affect the first-category joints (Table 4). However, significant differences in second-category joints (shoulder) were observed between breeds $(\mathrm{P}=0.023)$ : $\mathrm{CB}$ lambs showed the highest shoulder percentage (19.97 \pm 1.22 vs. 18.98 \pm 1.54$)$. Significant differences between breeds were observed in the lean $(\mathrm{P}=0.045)$ and total fat tissue

Table 2 - Means ( \pm standard deviation) of carcass traits of suckling lambs $(n=40)$ of the Canaria and Canaria Hair breeds

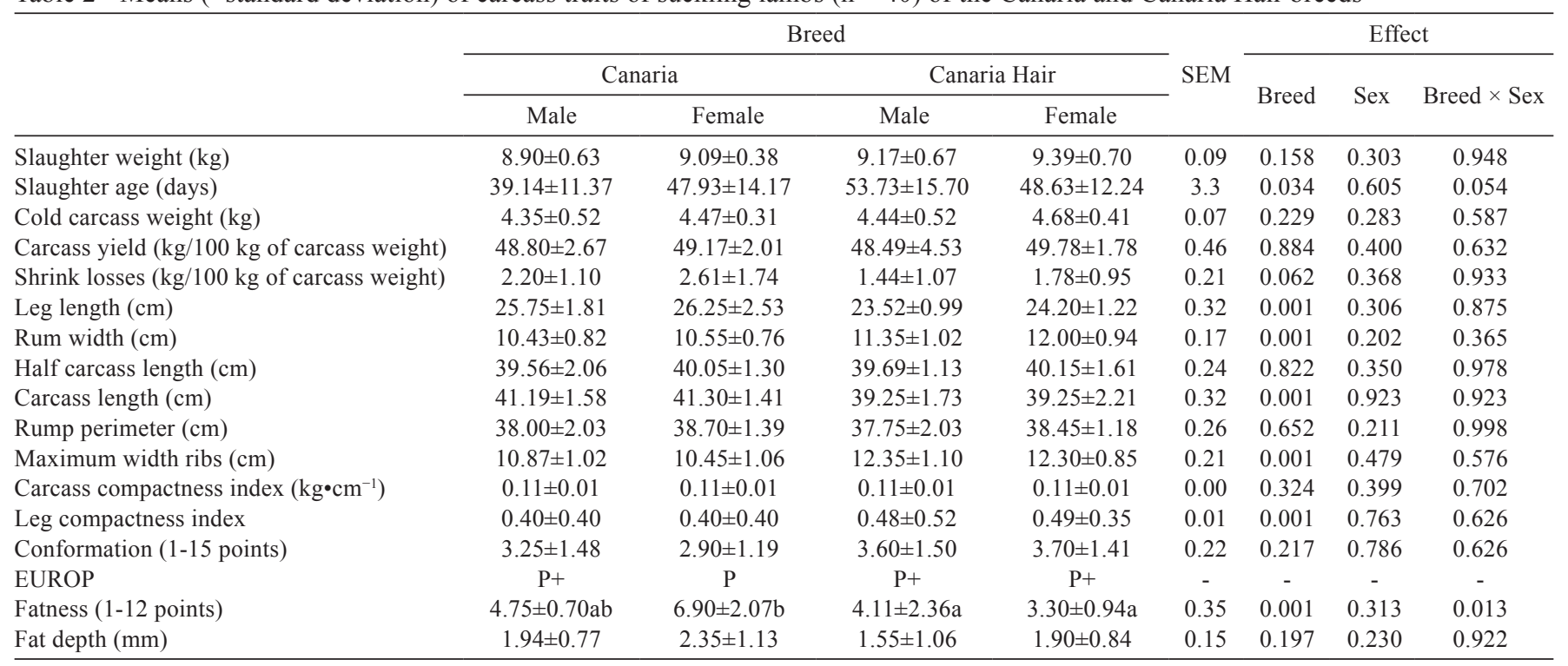

NS - non-significant $(\mathrm{P}>0.05)$; SEM - standard error of the mean.

$\mathrm{a}, \mathrm{b}-$ means in the same row showing different letters are significantly different $(\mathrm{P} \leq 0.05)$.

EUROP $-1=\mathrm{P}-; 2=\mathrm{P}$ (poor); $3=\mathrm{P}+; 4=\mathrm{O}-; 5=\mathrm{O}($ normal $) ; 6=\mathrm{O}+; 7=\mathrm{R}-; 8=\mathrm{R}($ good $) ; 9=\mathrm{R}+; 10=\mathrm{U}-; 11=\mathrm{U}($ very good $) ; 12=\mathrm{U}+; 13=\mathrm{E}-; 14=\mathrm{E}($ excellent $) ;$ and $15=\mathrm{E}+$. 
$(\mathrm{P}=0.033)$ contents with $\mathrm{CHB}$ lambs showing higher lean content (53.70 \pm 3.53 vs. $51.18 \pm 4.34)$, while CB lambs presented a higher total fat percentage $(24.10 \pm 6.33 v s$. 19.26 46.38 ).

Significant differences between sexes were observed in second-category joints (shoulder) $(\mathrm{P}=0.019)$. Males showed the highest shoulder percentage (19.97 $\pm 1.54 v s .18 .98 \pm 1.26)$. Lamb gender did not affect the tissue composition of the carcasses or L/TF, L/B and SF/IF ratios.

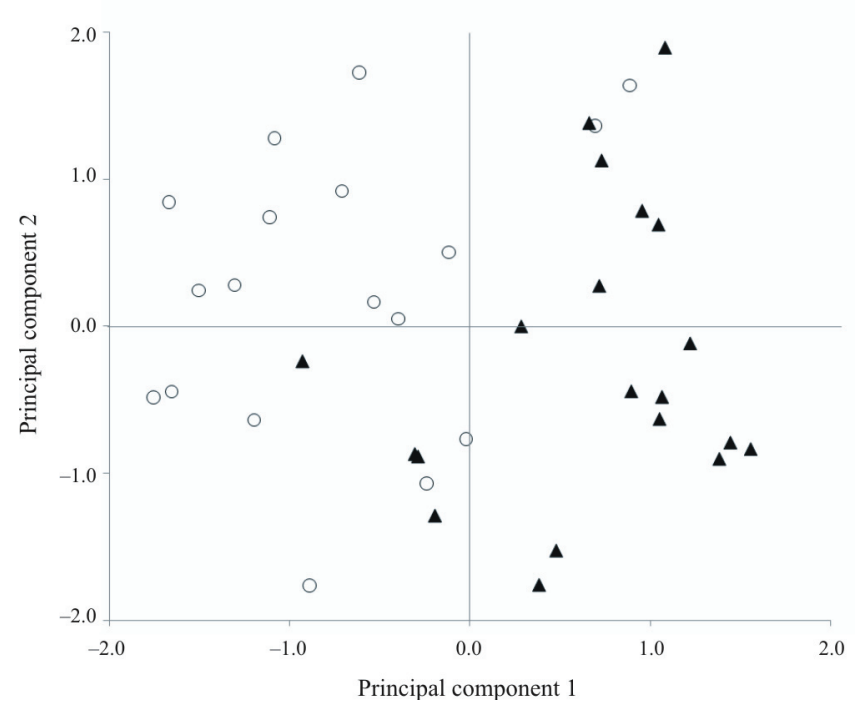

Figure 1 - Projection of the carcass measurement data of the two breeds studied (Canaria: $\boldsymbol{\Delta}$; Canaria Hair: ○) in the plane defined by the two principal components.

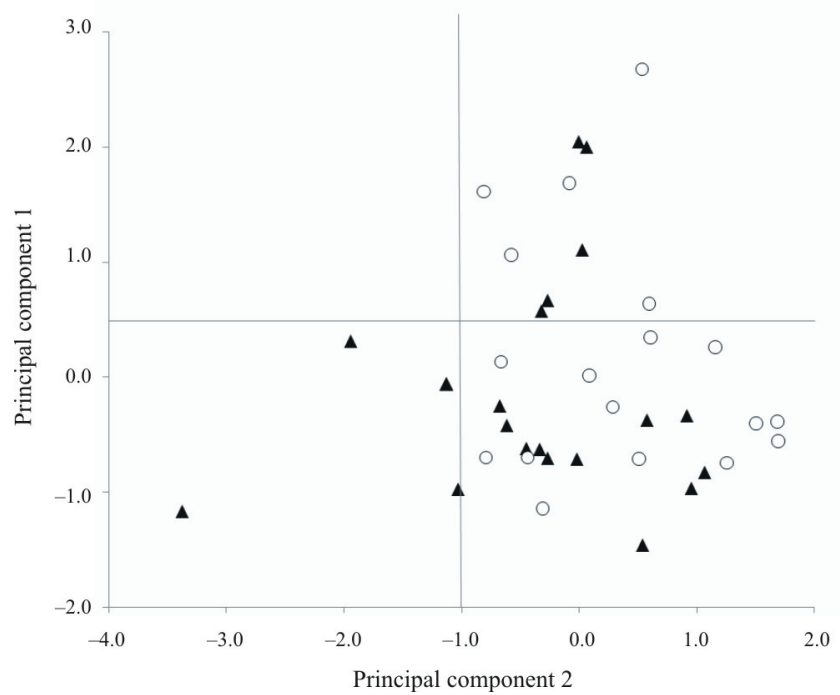

Figure 3 - Projection of the tissue composition data of the two breeds studied (Canaria Hair: $\boldsymbol{\Delta}$; Canaria: $\circ$ ) in the plane defined by the two principal components.
Table 3 - Results of the principal component analysis for the four principal components of the tissue composition

\begin{tabular}{lccc}
\hline Component & Eigenvalues & $\begin{array}{c}\text { Portion of variance } \\
(\%)\end{array}$ & $\begin{array}{c}\text { Cumulative variance } \\
(\%)\end{array}$ \\
\hline 1 & 3.06 & 61.25 & 61.25 \\
2 & 0.94 & 18.84 & 80.09 \\
3 & 0.67 & 13.40 & 93.49 \\
4 & 0.32 & 6.50 & 100.00 \\
\hline
\end{tabular}

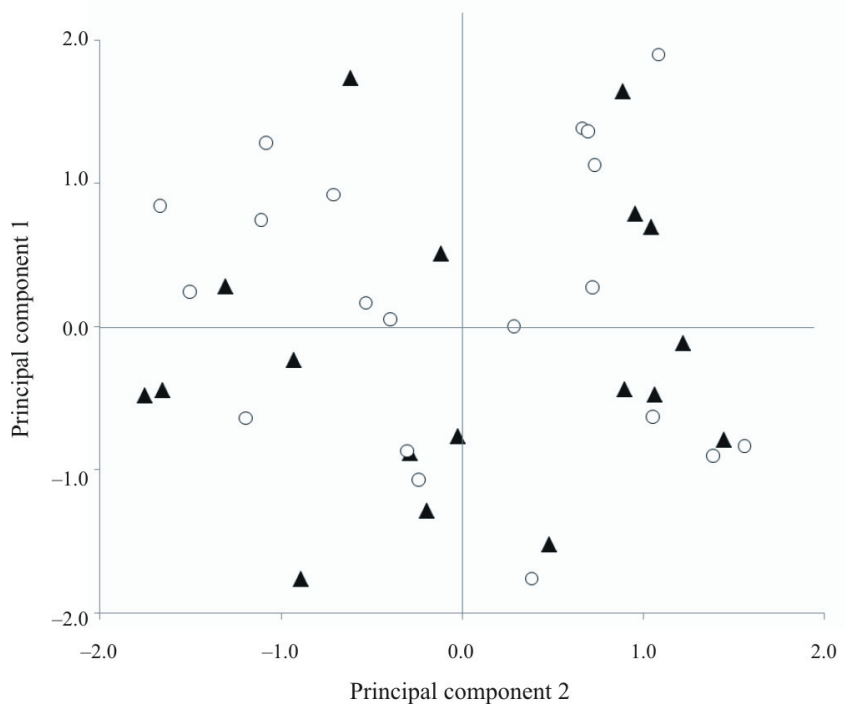

Figure 2 - Projection of the carcass measurement data of the two sexes (Male: $\boldsymbol{\Delta}$; Female: $\circ$ ) in the plane defined by two principal components.

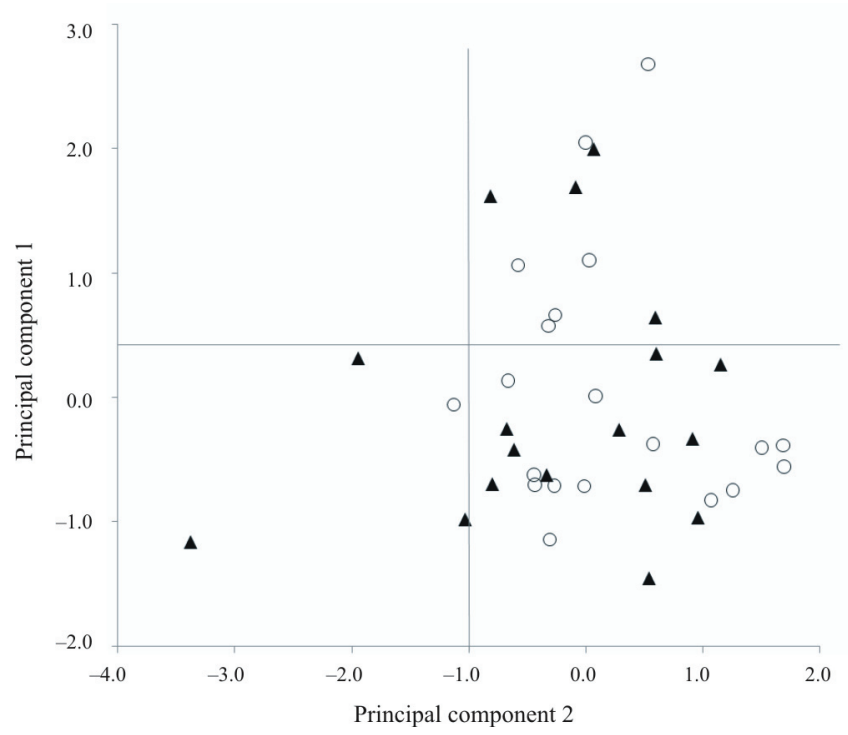

Figure 4 - Projection of the tissue composition data of the two sexes (Male: $\boldsymbol{\Delta}$; Female: $\circ$ ) in the plane defined by the two principal components.

R. Bras. Zootec., v.42, n.12, p.892-898, 2013 
Table 4 - Means ( \pm standard deviation) of the different categories of joints, percentages and ratios of the main tissues of lamb carcasses $(n=40)$ of Canaria and Canaria Hair suckling lambs

\begin{tabular}{|c|c|c|c|c|c|c|c|c|}
\hline & \multicolumn{4}{|c|}{ Breed } & \multirow{3}{*}{ SEM } & \multicolumn{3}{|c|}{ Effect } \\
\hline & \multicolumn{2}{|c|}{ Canaria } & \multicolumn{2}{|c|}{ Canaria Hair } & & \multirow{2}{*}{ Breed } & \multirow{2}{*}{ Sex } & \multirow{2}{*}{ Breed $\times$ sex } \\
\hline & Male & Female & Male & Female & & & & \\
\hline \multicolumn{9}{|c|}{ Commercial category ( $\mathrm{kg} / 100 \mathrm{~kg}$ of carcass weight) } \\
\hline 1st (leg+loin+anterior ribs) & $58.41 \pm 1.80$ & $59.48 \pm 1.98$ & $59.77 \pm 2.11$ & $60.30 \pm 3.08$ & 0.37 & 0.160 & 0.296 & 0.722 \\
\hline 2nd (shoulder) & $20.45 \pm 1.25$ & $19.58 \pm 1.12$ & $19.59 \pm 1.70$ & $18.37 \pm 1.13$ & 0.23 & 0.023 & 0.022 & 0.685 \\
\hline 3rd (neck+tail+breast) & $19.44 \pm 1.37$ & $19.08 \pm 1.78$ & $19.00 \pm 2.21$ & $18.94 \pm 2.27$ & 0.30 & 0.659 & 0.751 & 0.821 \\
\hline \multicolumn{9}{|c|}{ Composition tissues ( $\mathrm{kg} / 100 \mathrm{~kg}$ of carcass weight) } \\
\hline Lean & $50.03 \pm 4.95$ & $52.10 \pm 3.80$ & $54.90 \pm 3.56$ & $52.49 \pm 3.22$ & 0.66 & 0.045 & 0.896 & 0.085 \\
\hline Total fat & $21.57 \pm 4.25$ & $26.13 \pm 7.17$ & $18.75 \pm 8.16$ & $19.77 \pm 4.34$ & 1.09 & 0.033 & 0.185 & 0.398 \\
\hline Subcutaneous fat & $14.34 \pm 4.08$ & $18.42 \pm 6.86$ & $12.78 \pm 6.95$ & $12.80 \pm 4.78$ & 0.99 & 0.071 & 0.295 & 0.298 \\
\hline Intermuscular fat & $7.23 \pm 1.41$ & $7.70 \pm 1.61$ & $5.96 \pm 2.16$ & $6.97 \pm 1.20$ & 0.27 & 0.071 & 0.177 & 0.620 \\
\hline Bone & $23.87 \pm 2.66$ & $24.11 \pm 1.87$ & $24.89 \pm 3.50$ & $23.17 \pm 1.54$ & 0.40 & 0.966 & 0.371 & 0.239 \\
\hline Remainders & $1.94 \pm 0.52$ & $2.05 \pm 0.47$ & $2.36 \pm 0.65$ & $2.19 \pm 0.39$ & 0.08 & 0.111 & 0.853 & 0.426 \\
\hline \multicolumn{9}{|l|}{ Ratios: } \\
\hline Lean meat/total fat ratio & $2.41 \pm 0.64$ & $2.16 \pm 0.71$ & $4.43 \pm 4.74$ & $2.75 \pm 0.54$ & 0.41 & 0.120 & 0.245 & 0.389 \\
\hline Lean meat/bone ratio & $2.10 \pm 0.18$ & $2.16 \pm 0.19$ & $2.22 \pm 0.21$ & $2.26 \pm 0.10$ & 0.02 & 0.065 & 0.381 & 0.832 \\
\hline Subcutaneous fat/intermuscular fat ratio & $2.05 \pm 0.68$ & $2.44 \pm 0.86$ & $2.11 \pm 0.97$ & $1.92 \pm 0.81$ & 0.13 & 0.409 & 0.719 & 0.309 \\
\hline
\end{tabular}

SEM - standard error of mean.

NS - non-significant $(\mathrm{P}>0.05)$.

\section{Discussion}

The two breeds are separated by $90^{\circ}$ in the first component (Figure 1). Canaria-Hair-breed lambs were located mostly on the positive x-axis (component 1), because maximum width at rib level (Wr) and rump width (G) were the variables with the highest positive values. Therefore, CHB is the breed that produces best carcass quality because the carcasses are short, wide and compact and are, therefore, the more valued by the market (Diaz et al., 2006). There were no differences in the location of the breeds (Figures 3 and 4), regarding tissue composition. The carcasses of the $\mathrm{CB}$ lambs are located in the positive zone of the first component and only some carcasses of CHB are located in the negative zone of the first component. These correspond to carcasses with low lean and bone tissue, because these tissues showed high negative values in the components matrix $(-0.761$ and -0.750 , respectively).

In the analysis of variance, breed did not have any effect on carcass yield in $10 \mathrm{~kg}$ lambs. This result agrees with Pérez et al. (2007), who evaluated four different pure and crossed breeds (Merino Precoz Aleman, Suffolk, Merino Precoz Aleman $\times$ Suffolk, and Suffolk $\times$ Corriedale), and demonstrated that the genotype did not affect the carcass yield at $10 \mathrm{~kg}$ slaughter weight. The carcass yield found by these authors was higher (52.6\%) than that of $\mathrm{CB}$ and CHB lambs, perhaps because they are more specialised meat breeds.

Breed effect on carcass measurements was also observed by Miguélez et al. (2006) in suckling lambs of the Churra (dairy), Castellana (dairy-meat) and Ojalada (meat) breeds; and by Marino et al. (2008) in the Altamurana (dairy-meat) and Trimeticcio (meat) breeds. In agreement with Martínez-Cerezo et al. (2002), the CB lambs presented poor morphology for meat production (long carcass and narrow leg rump). Due to the wider rump and smaller leg length, CHB lambs presented carcasses with a more compact leg. Martínez-Cerezo et al. (2002) demonstrated that Churra lambs presented longer carcasses than the Rasa Aragonesa and Merino Español breeds, and these authors suggested that the morphology of the carcass in Churra lambs could be attributed to the dairy purpose of the breed. The differences observed in this study between breeds in carcass morphology could also be due to the different purposes of the breeds.

Canaria-breed lambs showed higher fatness scores. Differences between breeds in fatness have been attributed to differences in precocity or maturation of the breeds (Juárez et al. 2009). In the breed $\times$ sex interaction, it was observed that the higher fatness scores of CB were due to the high fat content of females. Díaz et al. (2006) also noted greater fatness in the females as a result of early maturing. Thus, the findings in relation to carcass fatness would indicate different precocity between breeds.

Canaria-breed lambs showed the highest shoulder percentage. Sanz et al. (2008), in Churra Tensina lambs, studying the evolution of different cuts during the growth period, conclude that the shoulder is a precocious joint, obtaining higher proportion at early ages. Thus, significant differences obtained in the proportion of second commercial cuts may be attributed to the precociousness of CB lambs. 
Canaria-Hair-breed lambs showed higher lean content, while CB lambs presented a higher total fat percentage. These results are in agreement with the results obtained in the subjective scoring of fatness (Table 1). Some authors have observed an increase in carcass fatness in dairy (Laborde et al., 2001) and precocious breeds (Ripoll et al., 2006). The higher total fat percentage of CB could, therefore, be due to their dairy purpose and precocity.

Sex did not affect any of the aforementioned variables (Table 2). Similarities in the growth rates of males and females explain these findings. Sex effect was only found in second-category joints. Male lambs showed the highest shoulder percentage. Díaz et al. (2006) obtained similar results and reported that male lambs presented greater development of neck and shoulder due to the response of certain muscles in these joints to the action of testosterone.

Lamb gender did not affect the tissue composition of the carcasses. In contrast, Díaz et al. (2006) observed significant differences between sexes in all tissues: males presented more bone and lean tissue than females, but less fat. These differences could be due to the fact that the slaughter age in this case was not the same between sexes. In this study, there were no differences in the slaughter age between males and females.

Gender did not affect L/TF, L/B or SF/IF ratios because males and females presented carcasses of similar tissue composition. Differences in the slaughter age between sexes could explain the results found by others authors, such as Santos et al. (2007), who observed, in suckling lambs, that there were significant differences between sexes in lean content and $\mathrm{L} / \mathrm{B}$ ratio and demonstrated that females presented higher values. Similarly, Díaz et al. (2003) found that females presented higher L/B and SF/IF ratios and lower L/TF ratios than males because the females showed higher total fat and subcutaneous percentage and lower bone percentage. The PC analysis did not show gender differences in the measurements and tissue composition of the carcass. These results agree with the analysis of variance.

\section{Conclusions}

Despite the short life span of the lambs studied, there are significant differences between the breeds, which are important features for the market, such as fatness and carcass compactness. Although fatness is essential for maintaining moisture, consumers prefer meat with a lower fat content; therefore, hair breed carcasses are more suitable for Mediterranean markets than Canaria breed carcasses.

\section{Acknowledgments}

This work was made possible by funding from the INIA (RTA/2006-00174-00-00), slaughterhouse of Tenerife and GORON SUR farm.

\section{References}

BARTON, R.A.; PHILLIPS, T.O.; CLARKE, E.A. Influence of sex on the fat lamb quality. In: ANNUAL CONFERENCE OF NEW ZEALAND SOCIETY OF ANIMAL PRODUCTION, 9., 1949, Wellington. Proceedings... Wellington: New Zealand Society of Animal Production, 1949. p.66-84.

BERMEJO, L.A.; MELLADO, M.; CAMACHO, A. et al. Factors influencing birth and weaning weight in canarian hair lambs. Journal Applied Animal Research, v.37, p.29-31, 2010.

BOCCARD, D.R.; DUMONT, B.L.; PEYRON, C. Etude de la production de la viande chez les ovins. VIII. Relations entre les dimensions de la carcasse d'agneau. Annales Zootechnic, v.13, p.367-378, 1964.

CAMACHO, A.; CAPOTE, J.; PEREZ, V. et al. Evolución del $\mathrm{pH}$ y del color de la carne y de la grasa en dos razas ovinas autóctonas. In: CONGRESO DE LA SOCIEDAD ESPAÑOLA DE OVINOTECNIA Y CAPRINOTECNIA (SEOC), 36., 2011, San Sebastian, España. Actas... San Sebastian: SEOC, 2011. p.209-212.

CAMACHO, A.; CAPOTE, J.; TORRES, A. et al. Efecto de la raza y el peso de sacrificio en la calidad de la carne en razas de ovino de pelo y ovino de lana en las Islas Canarias. In: CONGRESO DE LA SOCIEDAD ESPAÑOLA DE OVINOTECNIA Y CAPRINOTECNIA (SEOC), 35., 2010, Valladolid, España. Actas... Valladolid: SEOC, 2010. p.435-439.

CAÑEQUE, V.; PÉREZ, C.; VELASCO, S. et al. Carcass and meat quality of Light lambs using principal component analysis. Meat Science, v.67, p.596-605, 2004.

CIVIT, D.; GONZALEZ, C.; DÍAZ, M. et al. Influencia de la raza y el sexo sobre la calidad de la canal de corderos livianos. Veterinaria Argentina, v.26, n.253, 2009. Available at: <http://www. produccion-animal.com.ar/produccion-ovina/produccion-ovinacarne/02-calidad.pdf $>$. Accessed on: July 12, 2013.

COLOMER-ROCHER, F.; MORAND-FEHR, P.; KIRTON, A. et al. Métodos normalizados para el estudio de los caracteres cuantitativos y cualitativos de las canales ovinas. Madrid: Instituto Nacional de Investigaciones Agrarias (INIA), 1988. p.19-41.

DÍAZ, M.T.; DE LA FUENTE, J.; PÉREZ, C. et al. Body composition in relation to slaughter weight and gender in suckling lambs. Small Ruminant Research, v.64, p.126-132, 2006.

DÍAZ, M.T.; VELASCO, S.; PÉREZ, C. et al. Physico-chemical characteristics of carcass and meat manchego breed suckling lambs slaughtered at different weights. Meat Science, v.65, p.1085-1093, 2003.

GOBCAN. Gobierno de Canarias. Servicio de estadística, 2010. Available at: $<$ http://www.gobcan.es/agricultura/doc/otros/estadistica/ resumen/r2010.pdf $>$. Accessed on: July 20, 2012.

GONZÁLEZ, J.F.; HERNÁNDEZ, A.; MOLINA, J.M. et al. Comparative experimental Haemonchus contortus infection of two sheep breeds native to the Canary Islands. Veterinary Parasitology, v.153, p.374-378, 2008.

HERNÁNDEZ-CASTELLANO, L. Estudio comparativo de la calidad de la canal y de la carne de ovino de Raza Palmera y ovino comercializado en Canarias. 2010. 130f. Tesina de Grado (Licenciado en Veterinaria) - Facultad de Veterinaria/Universidad de las Palmas de Gran Canaria, Gran Canaria.

JUÁREZ, M.; HORCADA, A.; ALCALDE, M.J. et al. Meat and fat quality of unweaned lambs as affected by slaughter weight and breed. Meat Science, v.83, p.308-313, 2009. 
LABORDE, L.; MANDELL, B.; TOSH, J. et al. Breed effects on growth performance, carcass characteristics, fatty acid composition, and palatability attributes in finishing steers. Animal Science, v.79, p.355-365, 2001.

McMEEKAN, C.P. The cambrigge block test for fat lamb. In: ANNUAL MEETING OF SHEEP FARMERS, 8., 1939, Cambridge. Proceedings... Cambridge, 1939. p.52-57.

MARINO, R.; ALBENZIO, M.; ANNICCHIARICO, G. et al. Influence of genotype and slaughtering age on meat from Altamurana and Trimeticcio lambs. Small Ruminant Research, v.78, p.144-151, 2008.

MARTÍNEZ-CEREZO, M.S.; OLLETA, J.L.; SAÑUDO, C. et al. Calidad de la canal en tres razas ovinas españolas. Efecto del peso de nacimiento. In: CONGRESO DE LA SOCIEDAD ESPAÑOLA DE OVINOTECNIA Y CAPRINOTECNIA (SEOC), 27., 2002, Valencia, España. Actas...Valencia: SEOC, 2002. p.288-295.

MIGUÉLEZ, E.; ZUMALACÁRREGUI, J.M.; OSORIO, M.T. et al. Carcass characteristics of suckling lambs protected by the PGI "Lechazo de Castilla y León" european quality label: effect of breed, sex and carcass weight. Meat Science, v.73, p.82-89, 2006.

PALSSON, H.M. Meat qualities in the sheep with special reference to Scottish breed and crosses. Carcass measurement and sample joints as index of quality and composition. Journal Agricultural Science, v.24, p.544-574, 1939.

PEREZ, P.; MAINO, M.; MORALES, M.S. et al. Gender and slaughter weight effects on carcass quality traits of suckling lambs from four different genotypes. Small Ruminant Research, v.70, p.124-130, 2007.

RIPOLL, G.; DELFA, R.; JOY, M. et al. Evolución del color y de la dureza de la carne de tres tipos de cordero de Raza Churra Tensina. In: CONGRESO DE LA SOCIEDAD ESPAÑOLA DE OVINOTECNIA Y CAPRINOTECNIA (SEOC), 31., 2006, Zamora, España. Actas... Zamora: SEOC, 2006. p.73-75.

ROBINSON, J.J.; BINET, F.E.; DOIG, A.G. Fat lambs studies in Victoria. I. An assessment of the relative value of various external measurements for differentiating between various grades of export lams carcasses. Australian Journal Agricultural Research, v.7, p.345-365, 1956.

RODRÍGUEZ, A.B.; LANDA, R.; BODAS, R. et al. Carcass and meat quality of Assaf milk fed lambs: effect of rearing system and sex. Meat Science, v.80, p.225-230, 2008.

SANTOS, V.A.C.; SILVA, S.R.; MENA, E.G. et al. Live weight and sex effects on carcass and meat quality of "borrego terrinchoPDO” suckling lambs. Meat Science, v.77, p.654-661, 2007.

SANZ, A.; ÁLVAREZ RODRIGUEZ, L.; CASCAROSA, L. et al. Características de la canal de los tipos comerciales de cordero lechal, ternasco y pastenco en la raza Churra Tensina. Revista ITEA, v.104, p.42-57, 2008.

THWAITES, C.J.; YEATES, N.T.M.; POGUE, R.F. Objective appraisal of intact lamb and mutton carcasses. Journal Agricultural Science, v.63, p.415-420, 1964. 